\title{
RELATIONSHIP AMONG ACUTE PHASE PROTEINS IN TRANSITION PERIOD IN BUFFALOES
}

\author{
HANAN K. ELSAYED ${ }^{1}$; EMAN M. ABD- ELNASER ${ }^{2}$; AHMAD ABDEL-FATTAH AAMER ${ }^{1}$; \\ and SALLY ALI ABD ELSAYED ALI ${ }^{2}$ \\ ${ }^{1}$ Dept. of Animal Medicine, Faculty of Veterinary Medicine, Assiut University, Assiut, Egypt. \\ 2 Animal Health Research Institute, Assiut Branch
}

Received: 31 March 2019; Accepted: 30 April 2019

\begin{abstract}
The objectives of this study were to record the changes in some acute phase proteins (APPs) either positive or negative during transition period and to demonstrate the correlation between different APPs in the transition period. To achieve these objectives, 29 pregnant buffaloes were selected at $2^{\text {nd }}$ and $3^{\text {rd }}$ milk season from Ard El Kheir farm. The study was carried out in Assuit Governorate, Whole blood samples were collected from these buffaloes for determination of fibrinogen, blood plasma samples were collected for determination of vit. A and blood serum samples were collected for determination of serum albumin, serum total cholesterol, serum total bilirubin and serum haptoglobin). Blood samples were collected as the following: $(-21 \mathrm{~d}:-15 \mathrm{~d}),(-14 \mathrm{~d}$ : $-8 \mathrm{~d}),(-7 \mathrm{~d}$ : -1d), calving day, 3 d P.P, 7 d P.P, 14 d P.P and 28 d P.P. The study revealed significant changes in the concentration of some acute phase proteins, whether positive or negative. The mean values of fibrinogen revealed significant changes with maximum increase at day 3 P.P. Non significant changes in the mean values of haptoglobin with maximum increase one week pre partum. Significant increase in the mean values of total bilirubin at calving day and post partum periods compared with pre partum periods, reached maximum at day 14 P.P. The mean values of albumin revealed significant changes with maximum increase one week pre partum. A significant decrease in the mean values of total cholesterol at pre partum compared with post partum reached maximum at calving day compared with pre and post partum periods. A significant decrease in the mean values of vit. A reached maximum at day 7 P.P.
\end{abstract}

Key words: acute phase proteins, buffaloes, haptoglobin, total cholesterol, fibrinogen, pre partum, Assuit, post partum

\section{INTRODUCTION}

The Egyptian buffalo plays a crucial role in Egypt economy by their livestock productivity from milk and meat. The water buffalo is the major source for milk in Egypt as it contributes more than 50\% of the annual milk production in Egypt (Agriculture economic institute, 1997).

The transition period, as defined by Drackley (1999), is a stressful time for the health and productivity of dairy animals, and the most challenging stage in the lactation cycle when most metabolic disorders and infectious diseases occur. It is the period around calving constitutes late pregnancy and early lactation, generally 3 weeks before and 3 weeks after parturition. This period is characterized by tremendous metabolic and endocrine adjustments that the animals must

Corresponding author: Dr. Hanan K. Elsayed E-mail address: hanankamal726@yahoo.com Present address: Dept. of Animal Medicine, Faculty of Veterinary Medicine, Assiut University, Assiut, Egypt. experience from late gestation to early lactation (Drackley et al., 2001 and DeFrain et al., 2005) having a significant effect on the animal's health (Lippolis, 2008). This period is marked by changes; some of these are related to alterations increases in energy requirements driven by both fetal needs and lactogenesis, endocrine and metabolic preparing animals for childbirth and lactation (Morgante et al., 2012 and Piccione et al., 2012).

In periparturient dairy animals, in addition to the increase in ROS production, animals are typically in an inflammatory-like condition especially in the liver (Bertoni et al., 2008 and Trevisi et al., 2010\& 2012), even without signs of microbial infections or other pathologies (Petersen et al., 2004 and Sordillo et al., 2009).

Parturition, changes in homeostasis, metabolic and physiological challenges occurring in this stressful period as well as other external and internal harmful stimuli may contribute to the activation of the host immune system, including the initiation of 
inflammatory responses (Tóthová et al., 2014). These inflammatory markers are elevated at parturition and the days following in all animals, although these increases appear to be more pronounced in animals that go on to have more serious health complications (Huzzey et al., 2009). All dairy animals suffer from an inflammatory condition during their transition period, exerts several negative effects on metabolism, performances and fertility (Trevisi et al., 2011).

Acute phase response consists of a large number of behaviors, physiological, biochemical, and nutritional changes (Ceciliani et al., 2012). The most important metabolic changes include the highly increased or decreased production of a large family of proteins from the liver (the acute phase proteins) (Ceciliani et al., 2002 and Murata et al., 2004). Acute phase proteins (APPs) are blood proteins primarily synthetized by hepatocytes as part of the acute phase response (Cray et al., 2009) which released into the blood stream in response to a variety of stressors. In general, the main function of APPs is to protect the host against pathological damage, assist in the restoration of homeostasis and in the regulation of different stages of inflammation (Petersen et al., 2004).

The APPs can be produced by both hepatocytes and peripheral tissues, and can be classified according to their concentration in positive APPs, if they increase, or negative APPs if they decrease (Petersen et al., 2004, Ceron et al., 2005 and Eckersall \& Bell, 2010).

The plasma changes of +APPs (e. g. haptoglobin, ceruloplasmin) are useful indices to describe the severity of the inflammatory status, also in case of a subclinical form. While the assessment of -APPs (e. g. albumins, retinol binding protein, apolipoproteins) describe the extent and the consequences of the response to inflammation (Ceron et al., 2005, González et al., 2008 and Grossi, 2011).

Acute phase proteins (APPs) are blood proteins primarily synthesized by hepatocytes as part of the acute phase response. The acute phase response is a non-specific complex reaction of an organism, triggered by different stimuli (Cray et al., 2009). The APPs consist of negative and positive proteins that show a decrease and an increase in levels, respectively, in response to challenge or stressors (Eckersall, 2004, Murata et al., 2004 and Gruys et al., 2005).

Changes in acute phase proteins during transition period in dairy cattle have been widely investigated, however; few researches were carried out in buffaloes. To the best of our knowledge, the current study is considered as one of the first in the field to address water buffalo transition period by using APPs. Studies on APPs in buffaloes are scarce in Egypt. So, the main objectives of this study were to record the changes in some acute phase proteins (APPs) during transition period and to demonstrate the correlation between different APPs in the transition period.

\section{MATERIALS AND METHODS}

\section{1- Animals:}

The study was carried out on 29 clinically healthy, multiparous buffaloes at transition period (3weeks before calving and 4 weeks after calving), with average age of 2-4 years old from a private farm belongs to Assuit Governorate (Ard El- Kheir). Samples were collected from May to October, 2015. Buffaloes were fed daily on meal composed of corn, soybeans, wheat bran, silage, little amount of sunflower, hay, multi vitamins, mineral mixture, antioxidant, buffer, dibasic phosphate" only before calving"). Protein in ration usually $11 \%$, but at dry period reach $14-16 \%$. Water was supplied ad libitum.

\section{2- Clinical examination:}

All animals in the study were subjected to general clinical examination, where the clinical examination including body temperature, respiratory and pulse rates, ruminal movement, visual inspection of the udder, appetite as well as examination of mucous membranes was conducted according to Rosenberger (1990).

\section{3- Samples:}

Blood samples were collected in early morning; avoid stress or physical efforts as possible, avoid sick buffaloes, samples were kept in ice box and centrifuged within $2 \mathrm{~h}$ of collection. Three blood samples were collected by jugular vein puncture in vacuum tubes (Vacuette, Greiner Austria) containing no anti-coagulant, lithium-heparin, and K3EDTA.

Several blood samples were collected from each animal before calving, according to calving day, only samples at the $(-21),(-14)$ and $(-7)$ days pre calving were used, then at calving day, $3^{\text {rd }}, 7^{\text {th }}, 14^{\text {th }}$ and $28^{\text {th }}$ days post calving.

\section{4- Biochemical analysis:}

Measurement of fibrinogen by using the routine heat precipitation technique (Millar et al., 1971). Measurement of Retinol binding Protein (RBP, measured as retinol (vit. A) chemically by spectrophotometric method using Cecil Digital 
Ultraviolet Cambridge, England (CE, 292, Series2) (Carr and Price, 1926). Measurements of albumin, lipoproteins (indirectly measured as total cholesterol) and total bilirubin by using commercial test kits supplied by diamond diagnostics (Diamond diagnostics, Hannover, Germany) measured spectrophotometry using UV spectrophotometer (Optizen 3220 UV, Mecasys Co. Ltd, Korea). Spectrophotometeric assay was performed using spectrophotometer in the department of Animal Medicine- Faculty of Veterinary Medicine Assiut University, Assuit Egypt. Measurement of haptoglobin using Haptoglobin test kit (Catalog. No: WBE- 030 WKEA med supplies) by ELISA microplate reader (Elson, 1974 and Makimura \& Suzuki, 1982) in molecular biology unit Assiut University, Assuit Egypt.

\section{5- Statistical analysis:}

Values are presented as means \pm standard error of the mean (SEM). Statistical analysis of obtained data was carried out using general linear model (GLM procedure) of SAS System (2004). Two-way analysis of variance (ANOVA) with repeated measurements was carried out to study the effect of periods. The statistical significance of difference between period's means was determined using Duncan's Multiple Range Test (DMRT) (Steel and Torrie, 1980). All the variables were considered significant at $(\mathrm{p}<0.05)$. Pearson's coefficients of correlation were evaluated using the CORR procedure of SAS.

\section{RESULTS}

\section{I-Clinical examination:}

All examined animals were inspected for presence of any abnormal clinical signs. Clinical examination of the animals in this study revealed that body temperature, respiratory and pulse rates and ruminal movement within normal reference range. Also, udder and mucous membranes were apparently healthy. No abnormal clinical signs were recorded during the study period.

\section{II- Biochemical analysis:}

Results of selected measured positive acute phase proteins (Plasma fibrinogen, serum haptoglobin and total bilirubin) are illustrated in Table (1) and Figure $(2,3$ and 4). Mean values revealed significant ( $\mathrm{p}<$ 0.05 ) increase in plasma fibrinogen at calving day compared with pre calving periods, reached maximum at day 3 Post partum (P.P), followed by a significant $(\mathrm{p}<0.05)$ decrease at days 14 and 28 P.P, a non significant difference in serum haptoglobin during transition period but maximum increase occurred at $(-7 \mathrm{~d})$ pre partum and significant $(\mathrm{p}<$ $0.05)$ increase in serum total bilirubin at calving day and post calving periods compared with pre calving periods, reached maximum at day 14 P.P. Except one week before calving.

Table 1: Changes in selected positive acute phase proteins during transition period in buffaloes.

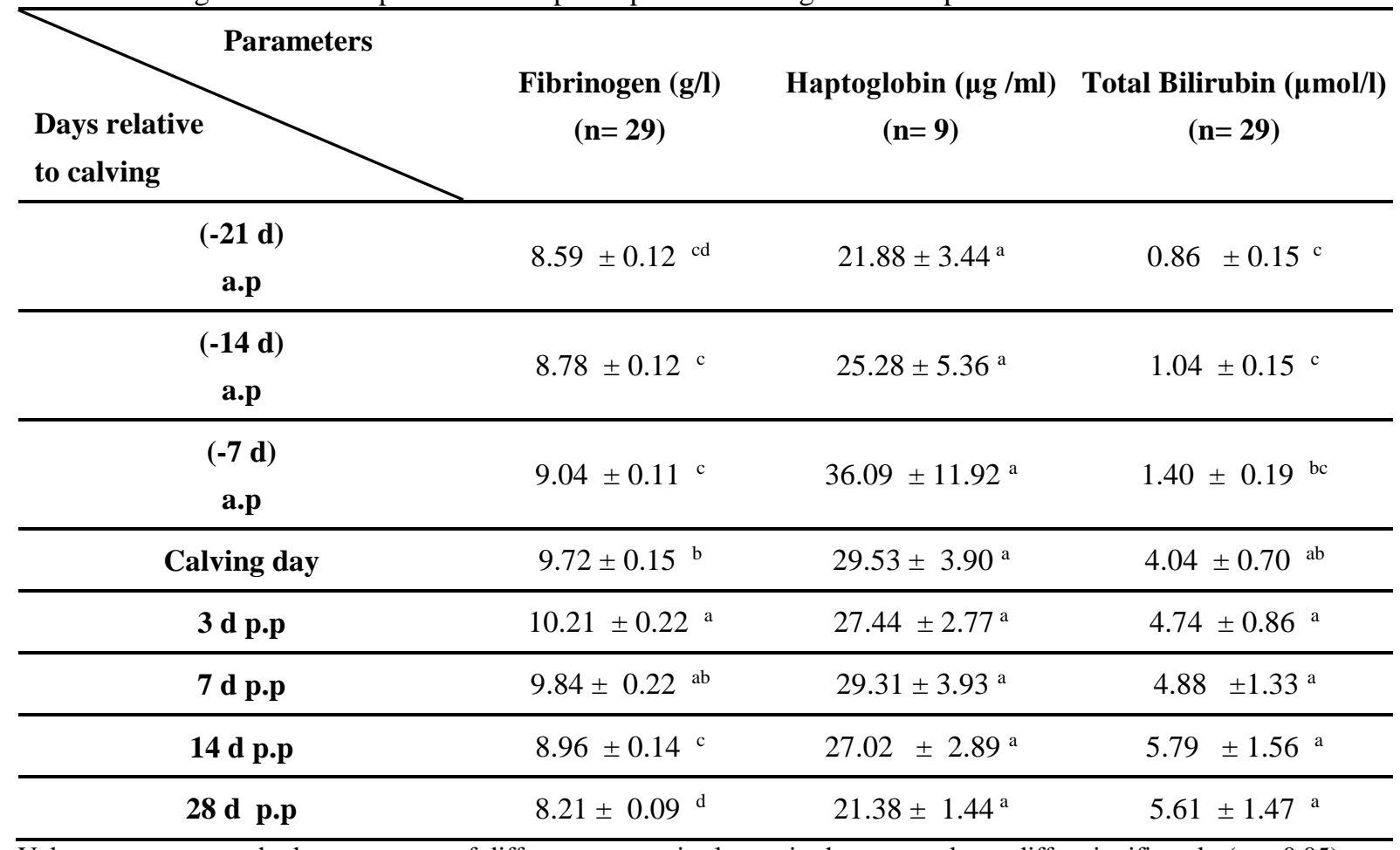

Values $=$ mean \pm standard error, means of different superscript letters in the same column differ significantly $(\mathrm{p}<0.05)$. a.p, ante partum; d p.p, day post partum 


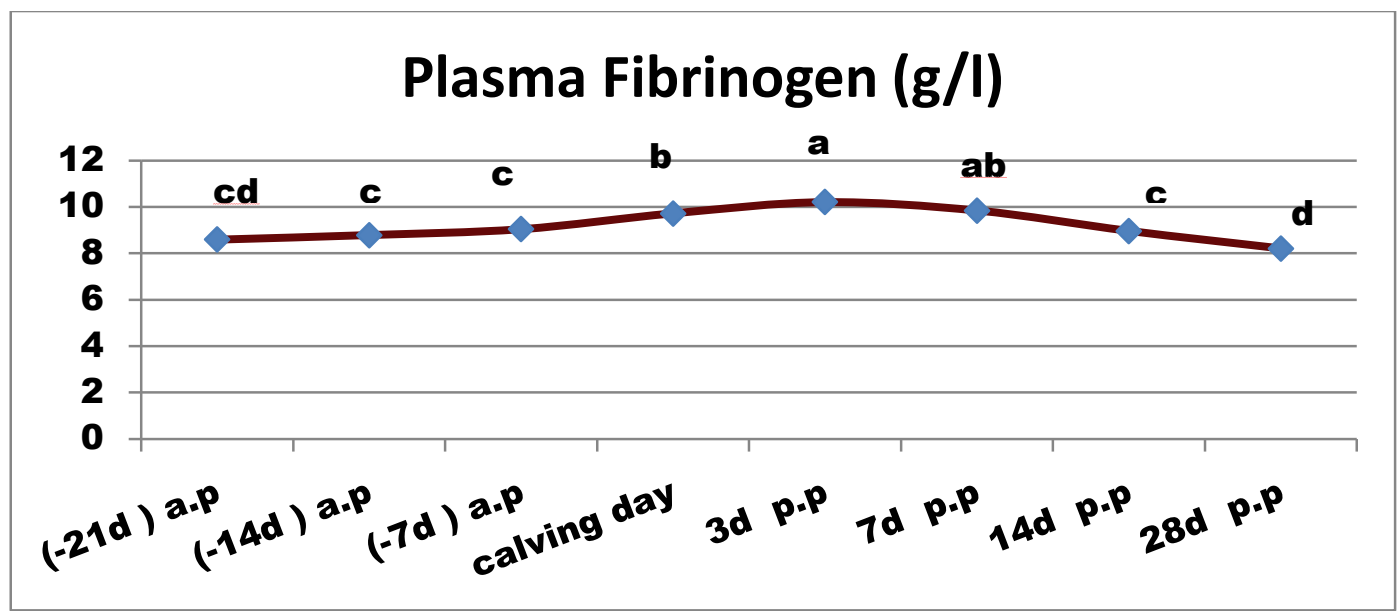

Figure (2): Changes in plasma fibrinogen concentrations during periparturient period.

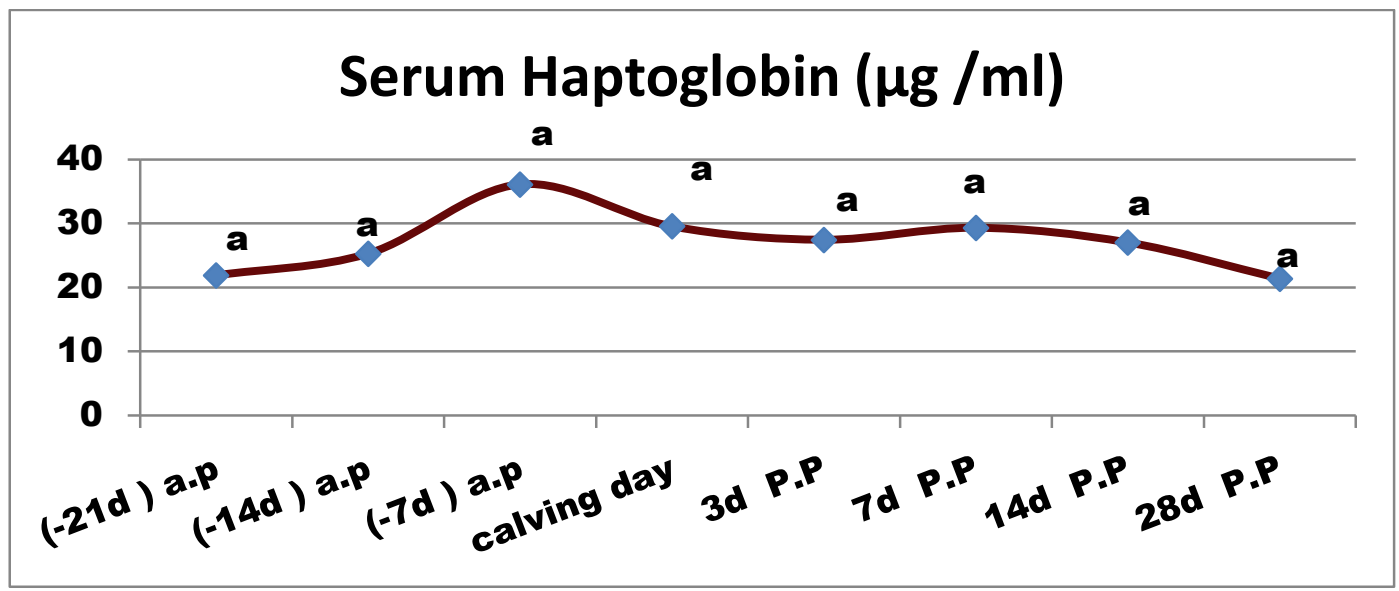

Figure (3): Changes in serum haptoglobin concentrations during periparturient period.

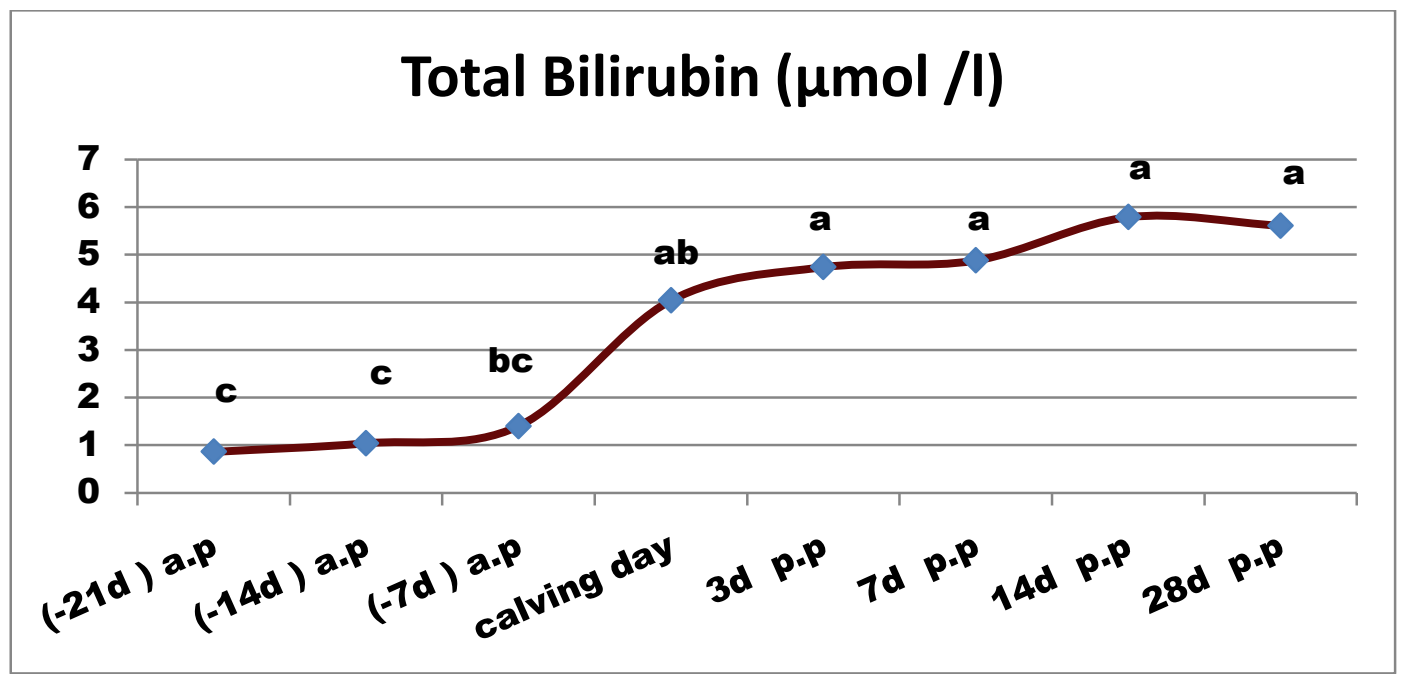

Figure (4): Changes in serum total bilirubin concentrations during periparturient period

Results of selected measured negative acute phase proteins (serum albumin, total cholesterol and vit. A) are illustrated in Table (2) and Figure (5,6 and 7). Mean values revealed significant $(\mathrm{p}<0.05)$ increase in serum albumin reached maximum at $(-7 \mathrm{~d})$ ante partum followed by significant $(\mathrm{p} \leq 0.05)$ decrease at calving day reached maximum at day 28 P.P, significant $(\mathrm{p}<0.05)$ decrease in serum total cholesterol at calving day compared with ante partum and post partum periods followed by significant $(\mathrm{p}<0.05)$ increase reached maximum at day 28 P.P., significant $(\mathrm{p}<0.05)$ decrease in serum vit. A reached maximum at day 7 P.P. followed by significant $(\mathrm{p}<0.05)$ increases at day 28 P.P. 
Table 2: Changes in selected negative acute phase proteins during transition period in buffaloes.

\begin{tabular}{|c|c|c|c|}
\hline $\begin{array}{l}\text { Days relative } \\
\text { to calving }\end{array}$ & $\begin{array}{l}\operatorname{Albumin}(g / l) \\
\qquad(\mathbf{n}=29)\end{array}$ & $\begin{array}{l}\text { Total Cholesterol }(\mathrm{mmol} / \mathrm{l}) \\
\qquad(\mathrm{n}=29)\end{array}$ & $\begin{array}{l}\text { Vit. A }(\mu \mathrm{g} / \mathrm{dl}) \\
\quad(\mathrm{n}=29)\end{array}$ \\
\hline $\begin{array}{c}(-21 d) \\
\text { a.p }\end{array}$ & $42.51 \pm 0.73^{c}$ & $1.46 \pm 0.05^{b}$ & $49.95 \pm 0.68^{b}$ \\
\hline $\begin{array}{c}(-14 d) \\
\text { a.p }\end{array}$ & $42.72 \pm 0.55^{c}$ & $1.40 \pm 0.03^{b}$ & $47.04 \pm 0.70^{c}$ \\
\hline $\begin{array}{l}(-7 d) \\
\text { a.p }\end{array}$ & $49.35 \pm 1.27$ & $1.18 \pm 0.03^{c}$ & $45.08 \pm 0.61^{c}$ \\
\hline Calving day & $46.77 \pm 1.34^{a b}$ & $0.82 \pm 0.04^{d}$ & $39.79 \pm 0.67^{\mathrm{d}}$ \\
\hline 3 d p.p & $44.65 \pm 0.85 b c$ & $1.06 \pm 0.04^{\mathrm{c}}$ & $36.83 \pm 0.75^{\mathrm{e}}$ \\
\hline 7 d p.p & $43.61 \pm 1.04^{c}$ & $1.08 \pm 0.04^{\mathrm{c}}$ & $34.44 \pm 0.71^{\mathrm{f}}$ \\
\hline 14 d p.p & $43.49 \pm 0.76$ & $1.42 \pm 0.07 \mathrm{~b}$ & $45.67 \pm 0.88^{c}$ \\
\hline 28 d p.p & $43.03 \pm 0.70^{\mathrm{c}}$ & $1.85 \pm 0.08^{\mathrm{a}}$ & $52.04 \pm 0.90^{a}$ \\
\hline
\end{tabular}

Values $=$ mean \pm standard error, means of different superscript letters in the same column differ significantly $(\mathrm{p}<0.05)$, a.p, ante partum; d p.p, day post partum

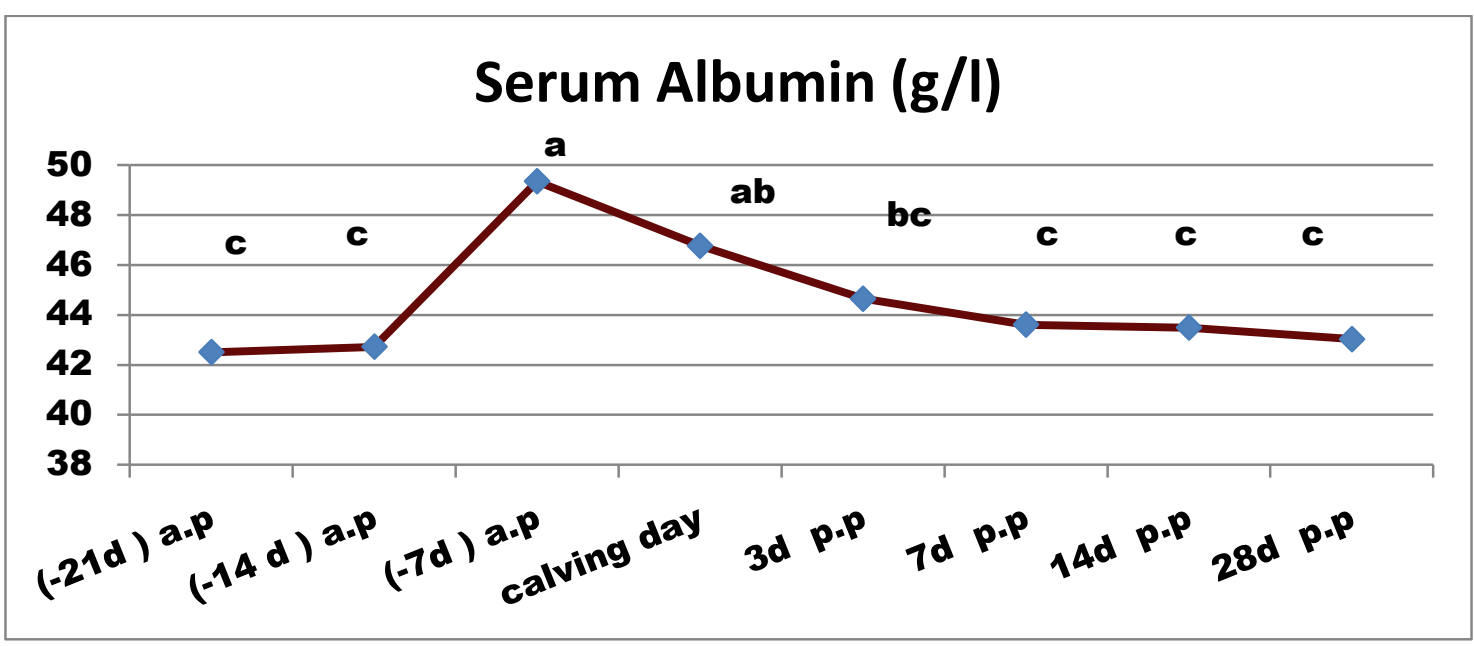

Figure (5): Changes in serum albumin concentrations during periparturient period.

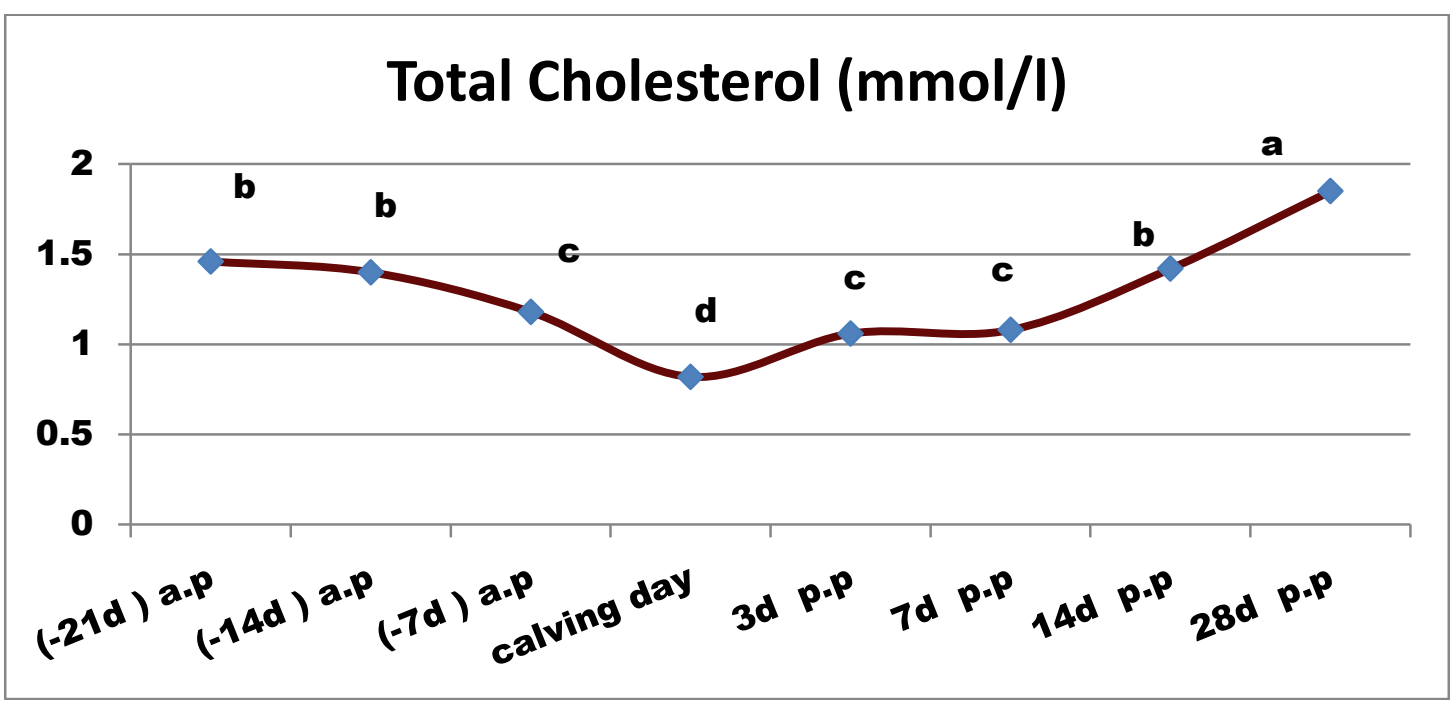

Figure (6): Changes in serum total cholesterol concentrations during periparturient period. 


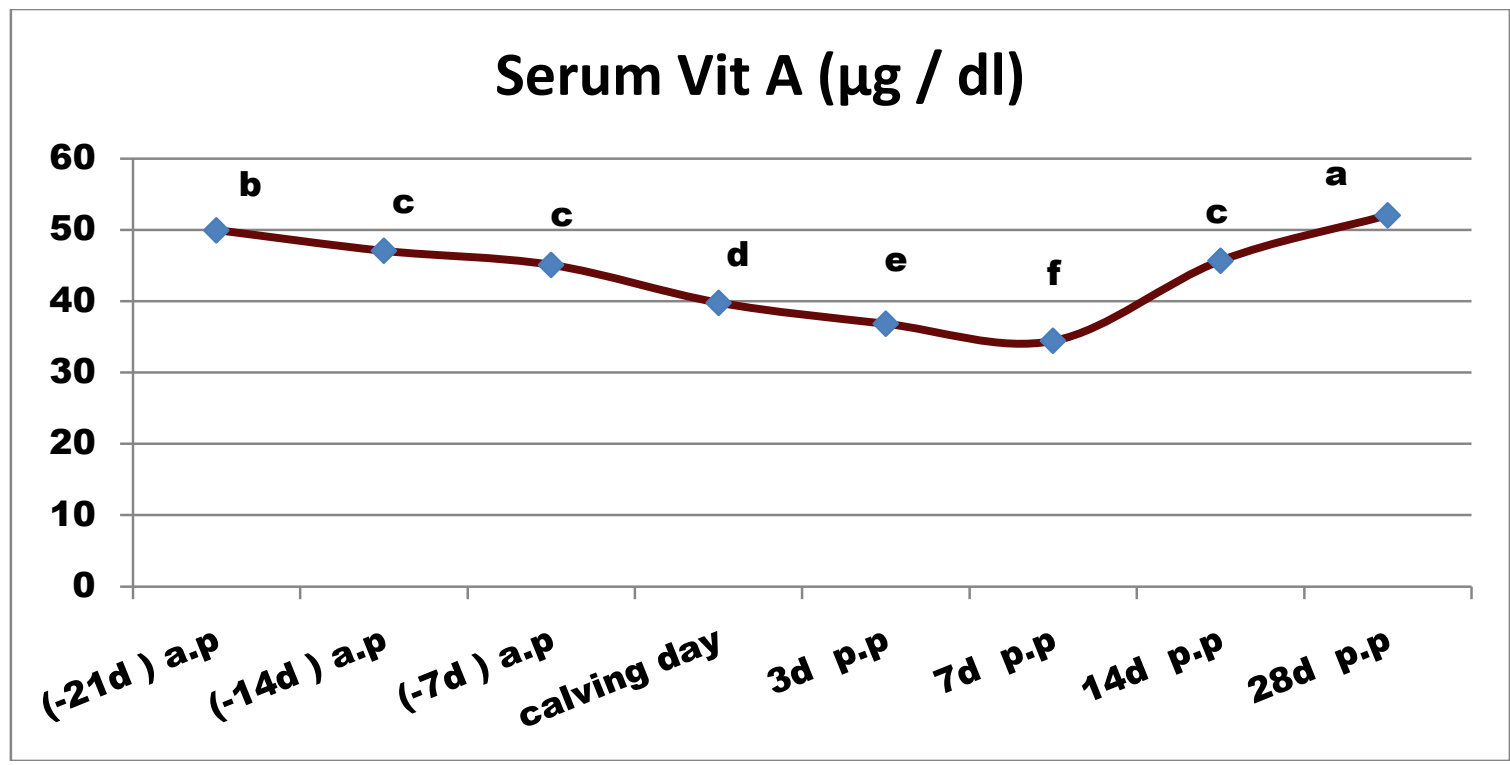

Figure (7): Changes in serum vit. A concentrations during periparturient period.

The obtained results showed that haptoglobin was positively correlated with fibrinogen. Total cholesterol and vit. A were negatively correlated with albumin, total bilirubin, fibrinogen and haptoglobin.

Table (3): Correlations among blood biochemical parameters in periparturient buffaloes

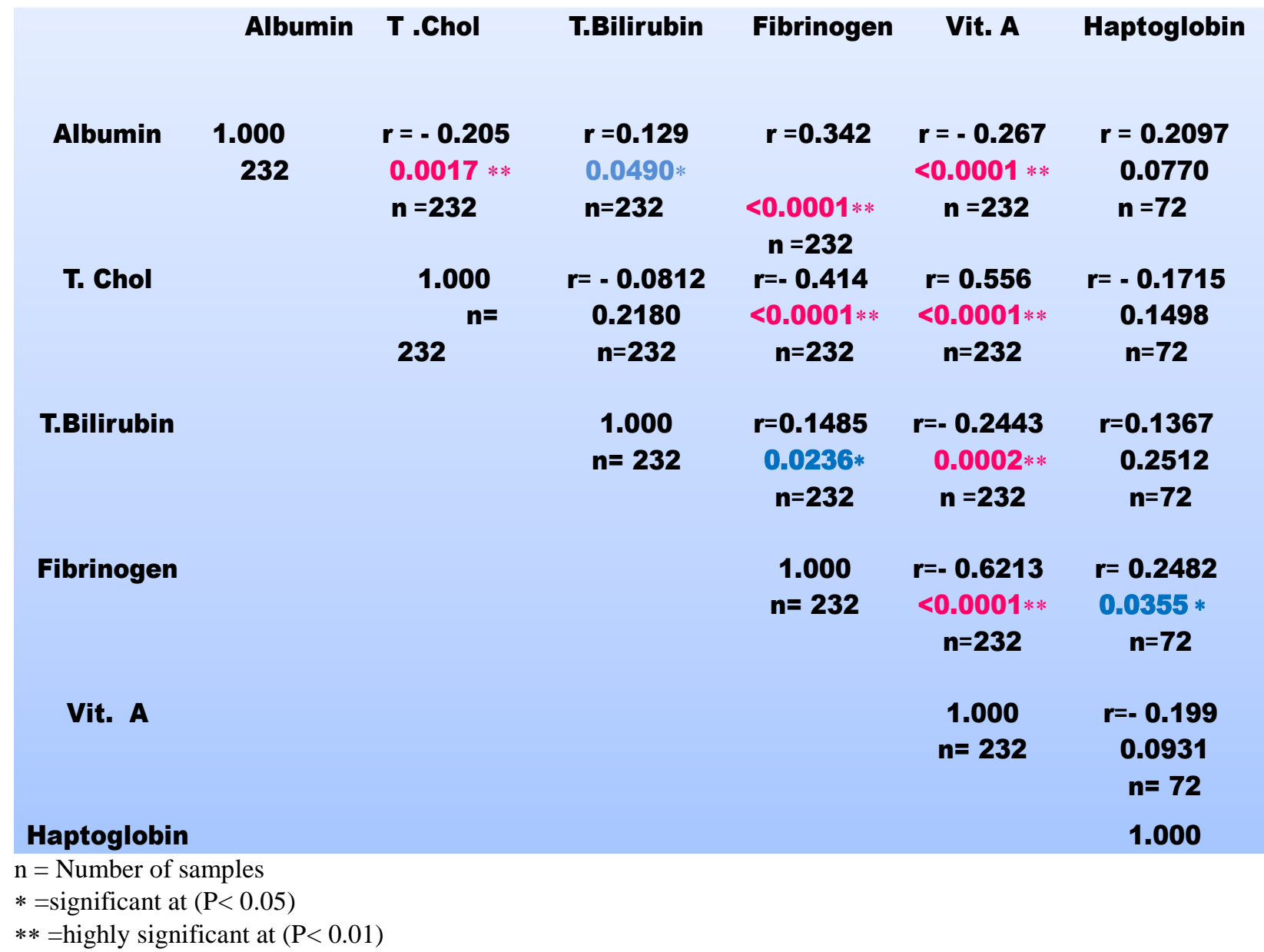




\section{DISCUSSION}

\section{1- Plasma fibrinogen (g/l):}

There was a significant increase $(\mathrm{p}<0.05)$ at calving day and reached maximum at day 3 P.P. The obtained result was lined with Zargham Khan et al. (1994) who reported that the plasma fibrinogen concentrations were higher in lactating than non lactating buffaloes.

There was a significant decrease $(\mathrm{p}<0.05)$ at days14 and 28 P.P. when compared with calving day and day 3 P.P. The obtained result may be attributed to the involvement of fibrinogen in homeostasis, providing a substrate for fibrin formation and in tissue repair, providing a matrix for the migration of inflammatory related cells (Thomas, 2000).

\section{2- Serum haptoglobin $(\mu \mathrm{g} / \mathrm{ml})$ :}

In our study, we noticed non significant changes in serum haptoglobin during periparturient period and its concentration reached the maximum value at (-7d) a.p and then decreased gradually after calving. This result was lined with Ametaj et al. (2005) and Kováč et al. (2009) who reported that serum Hp concentrations increased during pregnancy in animals and especially near parturition, probably because of up-regulation of its expression by cortisol and non-steroid fatty acids.

Results of HP in our study were lower than those reported by Tajik et al. (2011) who reported that the reference value for serum $\mathrm{Hp}$ of healthy water buffaloes was $0.129 \pm 0.06 \mathrm{~g} / \mathrm{l}$. This could be due to the different study conditions such as diet, climate, age, geographical location (Iranian study) and good management of the farm in the present study.

\section{3- Total bilirubin $(\mu \mathrm{mol} / \mathrm{l})$ :}

In the present study, there was a significant increase $(p<0.05)$ in the mean values of serum total bilirubin at calving day compared with (-21d) and (-14d) a.p .It can be mainly attributed to the lower synthesis of enzymes responsible for its clearance (Bertoni and Trevisi, 2013).This result was agreed with Omur et al. (2016) who reported that the level of total bilirubin increased at parturition and decreased after 3 weeks. Such increase may have resulted from the minimal level of cellular damage emerged in the liver due to the lipomobilization based on the energy deficit arising as the birth approaches.

Also, we noticed a significant increase $(\mathrm{p}<0.05)$ in the mean values of serum total bilirubin at post calving periods compared with pre calving periods. This increase may be resulted from the deficiency in liver functions developed due to the Negative Energy Balance (NEB) in that period (Bobe et al., 2004). This result was lined with Djokovic et al. (2011) who reported that the mean bilirubin concentration was significantly and markedly increased $(\mathrm{P}<0.05)$ in the early lactating compared to the late pregnant animals. Liver damage induces an increase in the serum total bilirubin, and the haemic compound is considered as a sensitive indicator for liver injury (Lubojacka et al., 2005). Also, it was lined with Celeska et al. (2015) who reported a significant increase $(p<0.05)$ of serum total bilirubin in dairy animals at day 5 post calving compared with day 5 pre calving and day 30 post calving. The author attributed an increased value of total bilirubin day 5 relative to calving, because the pathobiochemical processes of gluconeogenesis, glucogenolysis, phosphorilation, beta oxidation happened simultaneously in hepatocytes.

\section{4-Serum albumin $(\mathrm{g} / \mathrm{l})$ :}

In the present study, serum albumin levels showed a significant increase $(\mathrm{p}<0.05)$ at $(-7 \mathrm{~d})$ a.p compared with $(-14 \mathrm{~d})$ and $(-21 \mathrm{~d})$ a.p. This result could be attributed to endogenous production of antioxidants, such as albumin, in an attempt to cope with the increase in lipoperoxide production, especially one week before calving and early post-partum (Ghada et al., 2015). This result was lined with Montemurro et al. (1997) who reported high serum albumin levels in buffaloes at the end of pregnancy. Also, it was agreed with Cavestany et al. (2005), Djokovic et al. (2011) and Djokovic et al. (2013) who reported that albumin concentrations are known to be higher during the prepartum period than after parturition.

We noticed also that serum albumin level decreased at calving day compared to (-7d) a.p. It may be attributed to increase albumin consumption to avoid imbalance in oxidant/antioxidant status. The current study reported a significant decrease $(p<0.05)$ in serum albumin level at post calving periods compared with (-7d) a.p. This mentioned decrease may be caused by the transfer of albumin and $\gamma$ globulins from blood to the mammary gland (Kupczynski and Chudoba-Drozdowska, 2002), or it is probably due to decreased synthesis in the liver and increased utilization in the udder (Celeska et al., 2015). This result was lined with Tóthová et al. (2008) who stated that in postpartum period, the serum total protein and albumin levels were low as compared to the pre-partum and parturient periods. Also, it was lined with Celeska et al. (2015) who reported a significant decrease $(\mathrm{p}<0.05)$ in serum albumin at day 10 post calving compared with day 5 pre calving and day 30 post calving. Albumin and total protein concentrations showed changes at day 10 after calving, probably due to decreased synthesis in the liver and increased utilization in the udder. Seifi et al. (2007) also noticed that albumin was at lowest levels at day 8 post partum. There was a tendency for animals to have lower concentrations of serum albumin shortly after calving than at any other stage of the lactational cycle. This fall was explained 
in four possible ways: decreased synthesis of albumin by the liver, an increase in the rate of albumin catabolism, a dilution of albumin in the serum by an increase in blood volume, or an increase in the loss of albumin into the gut or extra vascular fluids including milk.

\section{5- Total cholesterol ( $\mathrm{mmol} / \mathrm{l})$ :}

There was a significant decrease $(\mathrm{p}<0.05)$ at $(-7 \mathrm{~d})$ a.p., calving day, days 3 and 7 P.P compared with (-21d) and (-14d) a.p. The lowest value was noticed at calving day followed by significant increase $(\mathrm{p}<$ 0.05 ) and reached maximum level at day 28 P.P. The decrease in serum total cholesterol concentration during the last stage of pregnancy is likely due to the increased requirement of fetal tissues as well as maternal glands for steroid hormone synthesis (Pysera and Opalka, 2000). This result was lined with Castillo et al. (2005), Nath et al. (2005), Seifi et al. (2007), Hagawane et al. (2009) and Quiroz-Rocha et al. (2009) who observed that the cholesterol level was low in dry pregnant buffaloes compared with lactation buffaloes. Also, it was lined with Ashmawy (2015b) who reported that the cholesterol level was low in the buffaloes near parturition. The lower cholesterol level in these species near parturition could be attributed to the increased utilization for steroid synthesis around parturition (Saeed et al., 2009 and Saeed \& Khan, 2012). Ling et al. (2003) and Yaylak et al. (2009) also found that the cholesterol level was low in the dry period and begin to increase gradually after calving to the peak at the mid lactation in dairy animals.

Also, Celeska et al. (2015) reported a significant increase $(\mathrm{p}<0.05)$ in serum total cholesterol at days 5,10 and 30 post calving compared with day 5 pre calving. Hypocholesteremia was maintained during the ante partal period in dairy animals, as a result of low "de novo" synthesis of cholesterol. During the post partum period, serum cholesterol concentration significantly increased, thus 30 and 60 days after calving they reached the highest value. Also, the liver ability for synthesis of apo lipoproteins for cholesterol transport was maintained and the highest significant cholesterol concentration was reached at day 30 and day 60 after calving (Celeska et al., 2015).

Piccione et al. (2012) reported that serum total cholesterol and triglycerides were significantly affected by the physiological status. There was a significant decrease $(\mathrm{p}<0.05)$ at days 3 and 7 P.P compared with day 28 P.P. It could be attributed to the switch in synthesis of lipoproteins from the hepatocytes in postpartum period as there was reduction in VLDL-c contain the large proportion of cholesterol among the lipoprotein (Mohammad, 2011). The higher level of cholesterol with advancement of lactation was a physiological adjustment to meet the lactation requirements (Ashmawy, 2015a).

The current study revealed lower levels of serum total cholesterol in buffaloes when compared with those reported by Tajik \& Nazifi (2011). Also, it was lower than those reported by Ghada et al. (2015). It may be attributed to lower blood cholesterol during summer than during winter season, in lactating Murrah buffaloes (Verma et al., 2000). This shows that cholesterol concentration decreases markedly with the increase in environmental temperature (Marai et al., 1995 and Habeeb et al., 1996). The marked decrease in cholesterol concentration may be due to dilution as a result of the increase in total body water or to the decrease in acetate concentration, which is the primary precursor for the synthesis of cholesterol (Verma et al., 2000).

\section{6- Serum Vit. A ( $\mu \mathrm{g} / \mathrm{dl})$ :}

In the present study, we noticed that there was a significant decrease $(\mathrm{p}<0.05)$ in serum vit. A level and reached maximum at day 7 P.P. It may be due to the transfer of large amounts of retinol and its derivatives into colostrum (Goff et al., 2002). This result was lined with Van Merris et al. (2004), Debier et al. (2005), Rezamand et al. (2007) and Abd Eldaim et al. (2010) who found that plasma retinol and Beta carotene levels in animals decrease at the end of gestation reach their lowest values around parturition, increase again during the first week of lactation and return to basal levels by 15 days after parturition.

The obtained results showed that haptoglobin was positively correlated with albumin, total bilirubin and fibrinogen. Total cholesterol and vit. A were negatively correlated with albumin, total bilirubin, fibrinogen and haptoglobin. These results showed the liver's response to avoid tissue damage, health problems and diseases that may occurred during transition period - indicated by increased production of natural antioxidant (albumin, haptoglobin and total bilirubin) and decreased production of lipoproteins due to enhanced lipomobilization and negative energy balance during the mentioned period. The different degree of correlation between various proteins is not surprising, particularly when the long period is considered (Bertoni et al., 2008).

\section{REFERENCES}

Abd Eldaim, M.A.; Kamikawa, A.; Soliman, M.M.; Ahmed, M.M.; Okamatsu-Ogura, Y.; Terao, A.; Miyamoto, T. and Kimura, K. (2010): Retinol binding protein 4 in dairy cows: Its presence in colostrums and alteration in plasma during fasting, inflammation, and the peripartum period. Journal of Dairy Research, 77: $27-32$. 
Agriculture economic institute (1997): Ministry of agriculture; Dokki; Egypt; in Arabic.

Ametaj, B.N.; Bradford, B.J.; Bobe, G.; Nafikov, R.A.; Lu, Y.; Young, J.W. and Beitz, D.C. (2005): Strong relationships between mediators of the acute phase response and fatty liver in dairy cows. Canadian Journal of Animal Science, 85: 165-175.

Ashmawy, N.A. (2015a): Blood Metabolic Profile and Certain Hormones Concentrations in Egyptian Buffalo during Different Physiological States. Asian Journal of Animal and Veterinary Advances, 10: 271280.

Ashmawy, N.A. (2015b): Changes in Peripheral Plasma hormone Concentrations and metabolites during the last trimester of pregnancy and around Parturition in the Egyptian Buffalo and Baladi cows. International Journal of Advanced Research, 3: $1377-1390$.

Bertoni, G. and Trevisi, E. (2013): Use of the liver activity index and other metabolic variables in the assessment of metabolic health in dairy herds. The Veterinary Clinics of North America: Food Animal Practice, 29: 413-431.

Bertoni, G.; Trevisi, E.; Han, X. and Bionaz, M. (2008): Effects of inflammatory conditions on liver activity in puerperium period and consequences for performance in dairy cows. Journal of Dairy Science, 91: 3300-3310.

Bobe, G.; Young, J.W. and Beitz, D.C. (2004): Invited review: Pathology, etiology, prevention, and treatment of fatty liver in dairy cows. Journal of Dairy Science, 87: 3105-3124.

Carr, F.H. and Price, E.A. (1926): Colour reactions attributed to vitamin A. Biochem. J. 20, 497.

Castillo, C.J.; Hemandez, A.; Bravo, M.; LopezAlonso, M.; Pereira, V. and Benedito, J.L. (2005): Oxidative status during late pregnancy and early lactation in dairy cows. Veterinary Journal, 169: 286-292.

Cavestany, D.; Blanch, J.E.; Kulcsar, M.; Uriarte, G.; Chilibroste, P.; Meikle, A.; Febel, H.; Ferraris, A. and Krall, E. (2005): Studies of the transition cow under a pasture-based milk production system: metabolic profiles. Journal of Veterinary Medicine Series A, 52: $1-7$.

Ceciliani, F.; Giordano, A. and Spagnolo, V. (2002): The systemic reaction during inflammation: the acute phase proteins. Protein Peptide Letters, 9: 211-223.

Ceciliani, F.; Ceron, J.J.; Eckersall, P.D. and Sauerwein, H. (2012): Acute phase proteins in ruminants. Journal of Proteomics, 75: 4207-4231.

Celeska, I.; Janevski, A.; Dzadzovski, I.; Ulchar, I. and Kirovski, D. (2015): The dynamics of biochemical parameters in blood of clinically healthy Holstein cows from day 5 before today 60 after calving. Macedonian Veterinary Review, 38: 189-193.

Ceron, J.J.; Eckersall, P.D. and Martinez-Subiela, $S$. (2005): Acute phase proteins in dogs and cats: current knowledge and future perspectives. Veterinary Clinical Pathology, 34: 85-99.

Cray, C.; Zaias, J. and Altman, N.H. (2009): Acute phase response in animals: a review. Comparative Medicine, 59: 517-526.

Debier, C.; Potter, J.; Goffe, C. and Larondell, Y. (2005): Present knowledge and unexpected behaviors of vitamin $\mathrm{A}$ and $\mathrm{E}$ in colostrum and milk. Livestock Production Science, 98: 135-147.

DeFrain, J.M.; Hippen, A.R.; Kalscheur, K.F. and Patton, R.S. (2005): Effects of feeding propionate and calcium salts of long-chain fatty acids on transition dairy cow performance. Journal of Dairy Science, 88: 983-993.

Djokovic, R.; Ilic, Z.; Kurcubic, V.; Petrovic, M. and Doskovic, V. (2011): Functional and morphological state of the liver in Simmental dairy cows during transitional period. Revue de Médecine Véterinaire, 162: 574-579.

Djokovic, R.; Kurcubic, V.; Ilic, Z.; Cincovic, M.; Petrovic, M.; Fratric, $N$. and Jasovic, B. (2013): Evaluation of metabolic status in Simmental dairy cows during late pregnancy and early lactation. Veterinarski arhiv, 83: 593-602.

Drackley, J.K. (1999): ADSA Foundation Scholar Award. Biology of dairy cows during the transition period: the final frontier? Journal of Dairy Science, 82: 2259-2273.

Drackley, J.K.; Overton, T.R. and Douglas, G.N. (2001): Adaptations of glucose and longchain fatty acid metabolism in liver of dairy cows during the periparturient period. Journal of Dairy Science, 84: 100-112.

Eckersall, P.D. (2004): The time is right for acute phase protein assays. Veteinary Journal, 168: 3-5.

Eckersall, P.D. and Bell, R. (2010): Acute phase proteins: Biomarkers of infection and inflammation in veterinary medicine. The Veterinary Journal, 185: 23-27.

Elson, E.C. (1974): Quantitative determination of serum haptoglohin. American Journal of Clinical Pathology, 62: 655-663.

Ghada, A.E.M.; Eman, M.A-E. and Hanan, K.E. (2015): Preliminary study on lipid profile with relation to total antioxidant capacity and some hematological and biochemical changes pre-post-partum buffalo heifers at assuite city. Assiut Veterinary Medicine Journal, 61: 159-165. 
Goff, J.P.; Kimura, K. and Horst, R.L. (2002): Effect of mastectomy on milk fever, energy, and vitamins $\mathrm{A}, \mathrm{E}$, and $\mathrm{b}$-carotene status at parturition. Journal of Dairy Science, 85: 1427-1436.

González, F.H.D.; Tecles, F.; Martınez-Subiela, S.; Tvarijonaviciute, A.; Soler, L. and Ceron, J.J. (2008): Acute phase protein response in goats. Journal of Veterinary Diagnostic Investigation, 20: 580-584.

Grossi, P. (2011): Tansition period of dairy cows and inflammation: A novel index to assess the individual response, pre-calving treatments aiming to mitigate it and consequences on productive and reproductive performances. PHD.

Gruys, E.; Toussaint, M.J.M.; Niewold, T.A.; Koopmans, S.J. (2005): Acute phase reaction and acute phase proteins. Journal of Zhejiang University Science B, 6: 1045-1056.

Habeeb, A.A.M.; El-Masry, K.A.; Aboulnaga, A.I. and Kamal, T.H. (1996): The effect of hot summer climate and level of milk yield on blood biochemistry and circulating thyroid and progesterone hormones in Friesian cows. Arab Journal of Nuclear Sciences and Applications, 29: 161-173.

Hagawane, S.D.; Shinde, S.B. and Rajguru, D.N. (2009): Haematological and blood biochemical profile in lactating buffaloes in and around Parbhani city. Veterinary World, 2: 467-469.

Huzzey, J.M.; Duffield, T.F.; LeBlanc, S.J.; Veira, D.M.; Weary, D.M. and von Keyserlingk, M.A.G. (2009): Short communication: Haptoglobin as an early indicator of metritis. Journal of Dairy Science, 92: 621-625.

Kováč, G.; Tóthová, C.; Nagy, O.; Seidel, H. and Konvičná, K. (2009): Acute Phase Proteins and their Relation to Energy Metabolites in Dairy Cows during the Pre- and Postpartal Period. Acta Veterinaria Brno, 78: 441-447.

Kupczynski, $R$. and Chudoba-Drozdowska, B. (2002): Values of selected biochemical parameters of cows blood during their drying-off and the beginning of lactation. Electronic Journal of Polish Agriculture Universties-Vet Med 5.

Ling, K.; Jaakson, H.; Samarutel, J. and Leesmac, A. (2003): Metabolic status and body condition score of Estonian Holstein cows and their relation to some fertility parameters. Veterinanja Ir. Zootechnika, 24: 94-100.

Lippolis, J.D. (2008): Immunological signaling networks: integrating the body's immune response. Journal of Animal Sciences, 86: 5363.

Lubojacka, V.; Pechova, A.; Dvorak, R.; DrastIch, P.; Kummer, V. and Poul, J. (2005): Liver steatosis following supplementation with fat in dairy cows diets. Acta VeterinariaBrno, 74: 217-224.

Makimura, S. and Suzuki, N. (1982): Quantitative determination of bovine serum haptoglobin and its elevation in some inflammatory diseases. Japanese Journal of Veterinary Science, 44: 15-21.

Marai, I.F.M.; Habeeb, A.A.M.; Daader, A.H. and Yousef, H.M. (1995): Effect of Egyptian subtropical conditions and the heat stress alleviation techniques of water spray and diaphoretics on the growth and physiological functions of Friesian calves. Journal of Arid Environments, 30: 219-225.

Millar, H.R.; Simpson, J.G. and Stalker, A.L. (1971): An evaluation of the heat precipitation method for the plasma fibrinogen estimation. Journal of Clinical Pathology, 24: 827-830.

Mohammad, A.Q. (2011): A Study of some Haematological and Biochemical Parameters in Late Pregnancy, Parturition and early Lactation in Crossbred Cows. M.V.Sc Thesis, College of Veterinary Medicine, University of Basrah.

Montemurro, N.; Pacelli, C. and Borghese, A. (1997): Blood metabolites change in milking buffalo cows. Bubalus Bubalis, 3: 69-78.

Morgante, M.; Gianesella, M.; Casella, S.; Stelletta, C.; Cannizzo, C.; Giudice, E. and Piccione, G. (2012): Response to glucose infusion in pregnant and nonpregnant ewes: changes in plasma glucose and insulin concentrations. Comparative Clinical Pathology, 21: 961965.

Murata, H.; Shimada, N.; Yoshioka, M. (2004): Current research on acute phase proteins in veterinary diagnosis: An overview. Veterinary Journal, 168: 28-40.

Nath, H.C.; Baruah, K.K.; Baruah, A.; Sarmah, H.D. and Sarmah, B.C. (2005): Serum cholesterol and protein in pre, peri and postpartum cows. Indian Veterinary Journal, 82: 519-521.

Omur, A.; Kirbas, A.; Aksu, E.; Kandemir, F.; Dorman, E.; Kaynar, $O$. and Ucar, $O$. (2016): Effects of antioxidant vitamins (A, D, E) and trace elements $(\mathrm{Cu}, \mathrm{Mn}, \mathrm{Se}, \mathrm{Zn})$ on some metabolic and reproductive profiles in dairy cows during transition period. Polish Journal of Veterinary Sciences, 19: 697-706.

Petersen, H.H.; Nielsen, J.P. and Heegaard, P.M.H. (2004): Application of acute phase protein measurements in veterinary clinical chemistry. Veterinary Research, 35: 136-187.

Piccione, G.; Messina, V.; Marafioti, S.; Casella, S.; Giannetto, C. and Fazio, F. (2012): Changes of some haematochemical parameters in dairy cows during late gestation, post partum, lactation and dry periods. Veterinaria Medicina Zootecnia, 58: 59-64. 
Pysera, B. and Opalka, A. (2000): The effect of gestation of dairy cows on lipid and lipoprotein patterns and composition in serum during winter and summer feeding. Journal of Animal and Feed Science, 9: 411 -424.

Quiroz-Rocha, G.F.; LeBlanc, S.J.; Duffield, T.F.; Wood, D.; Leslie, K.E. and Jacobs, R.M. (2009): Reference limits for biochemistry and haematological analyses of dairy cows one week before and one week after parturition. Canadian Veterinary Journal, 50: 383-388.

Rezamand, P.; Hoagland, T.A.; Moyes, K.M.; Silbart, L.K. and Andrew, S.M. (2007): Energy status, lipid-soluble vitamins, and acute phase proteins in periparturient Holstein and Jersey dairy cows with or without subclinical mastitis. Journal of Dairy Science, 90: 5097-5107.

Rosenberger, G. (1990): Clinical Examination of Cattle. Paul Parey, Berlin/Hamburg, 2 nd Ed,68.

Saeed, A. and Khan, I. (2012): Alterations in serum lipids and lipoproteins profile of pregnant camels (camelus dromedarius) at term. Comparative Clinical Pathology, 21: 10191021.

Saeed, A.; Khan, I.A. and Hussein, M.M. (2009): Change in biochemical profile of pregnant camels (Camelus dromedarius) at term. Comparative Clinical Pathology, 18: 139143.

SAS-Statistical Analysis System (2004): SAS User's Guide: Statitics. SAS Inst. Inc., Cary, NC; Version 9.1 for Window.

Seifi, H.A.; Gorji-Dooz, M.; Mohri, M.; DalirNaghadeh, B. and Farzaneh, N. (2007): Variations of energy-related biochemical metabolites during transition period in dairy cows. Comparative Clinical Pathology, 16: 253-258.

Sordillo, L.M.; Contreras, G.A. and Aitken, S.L. (2009): Metabolic factors affecting the imflammatory response of periparturient dairy cows. Animal Health Research Reviews, 10: 53-63.

Steel, R.G.D. and Torrie, J.H. (1980): Principle and Procedures of Statistics A Biometrical Approach. $2^{\text {nd }}$ ed., McGraw-Hill Inc., New York.

Tajik, J. and Nazifi, S. (2011): Serum Concentrations of Lipids and Lipoproteins and Their Correlations together and with Thyroid Hormones in Iranian Water Buffalo (Bulbalus bulbalis). Asian Journal of Animal Sciences, 5: 196-201.

Tajik, J.; Nazifi, S.; Eskandarzadeh, N.; Sepehrimanesh, M. and Basaki, M. (2011): Serum haptoglobin, amyloid A, and sialic acid values in healthy water buffalo. Online
Journal of Veterinary Research, 15: 270276.

Thomas, J.S. (2000): Overview of plasma proteins. In: Feldman, B.F.; Zinkl, J.G.; Jain, N.C. (eds.): Schalm's Veterinary Hematology. Lippincott Williams \& Wilkins, Philadelphia: 891-898.

Tóthová, C.; Nagy, O. and Kovác, G. (2014): Changes in the concentrations of selected acute phase proteins and variables of energetic profile in dairy cows after parturition, Journal of Applied Animal Research, 42: 278-283.

Tóthová, C.S.; Nagy, O.; Seidel, H.; Konvičná, J.; Farkašová, Z. and Kováč, G. (2008): Acute phase proteins and variables of protein metabolism in dairy cows during the pre- and postpartal period. Acta Veterinaria Brno, 77: 51-57.

Trevisi, E.; Zecconi, A.; Bertoni, G. and Piccinini, R. (2010): Blood and milk immune and inflammatory profiles in periparturient dairy cows showing a different liver activity index. Journal of Dairy Research, 77: 310-317.

Trevisi, E.; Amadori, M.; Archetti, I.; Lacetera, N. and Bertoni, G. (2011): Inflammatory response and acute phase proteins in the transition period of high-yielding dairy cows. In Veas, F. (Ed.), Acute Phase Protein - Book 2 (pp. 355-380).

Trevisi. E.; Amadori, M.; Cogrossi, S.; Razzuoli, E. and Bertoni, G. (2012): Metabolic stress and inflammatory response in high-yielding, periparturient dairy cows. Research in Veterinary Science, 93: 695-704.

Van Merris, V.; Meyer, E.; Duchateau, L.; Blum, J. and Burvenich, C. (2004): All-trans retinoic acid is increased in the acute phase-related hypo retinemia during Escherichia coli mastitis. Journal of Dairy Science, 87: 980987.

Verma, D.N.; Lal, S.N.; Singh, S.P.; Parkash, O.M. and Parkash, O. (2000): Effect of season on biological responses and productivity of buffalo. International Journal of Animal Science, 15: 237- 244.

Yaylak, E.; Yenisey, C. and Seyrek, K. (2009): Effect of Lameness, stage of lactation and body condition score on some Blood Parameters in Holstein Cows. Asian Journal of Animal and veterinary Advances, 4: 245-251.

Zargham Khan, M.; Muhammad, G.; Umar, A. and Ali Khan, S. (1994): Preliminary observations on plasma Fbrinogen and plasma protein concentrations and on plasma protein: Fbrinogen ratios in clinically healthy buffaloes. Veterinary Research Communications, 18: 103-107. 


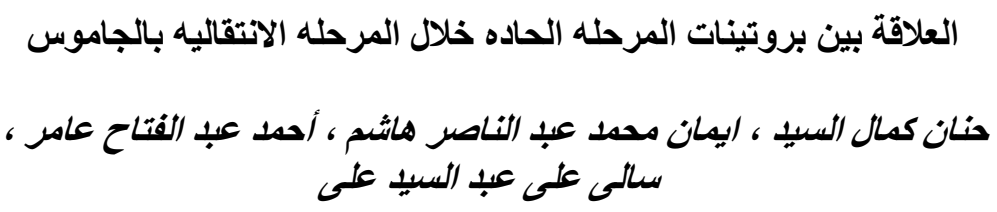

E-mail: hanankamal726@yahoo.com Assiut University web-site: www.aun.edu.eg

استهدفت هذه الدراسة توضيح التغيرات في بروتينات المرحلة الحادة سواء كانت موجبة أو سالبة وحساب معامل الارتباط بين

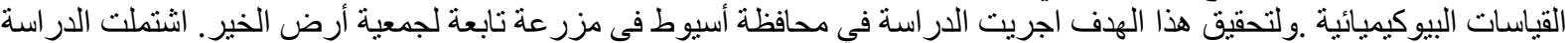

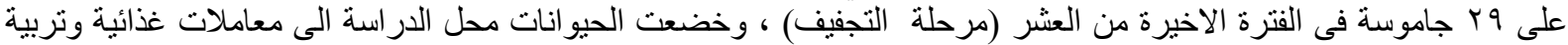

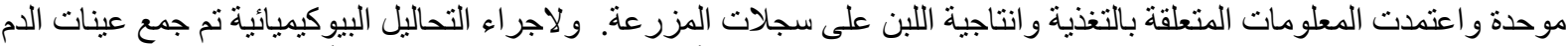

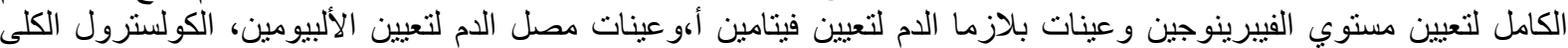

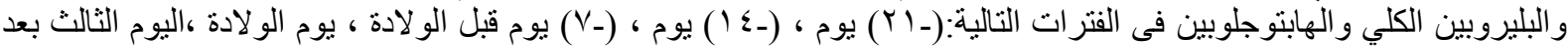

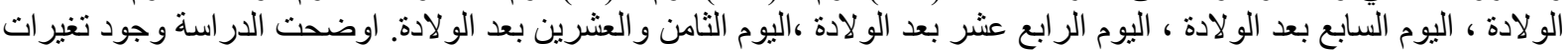

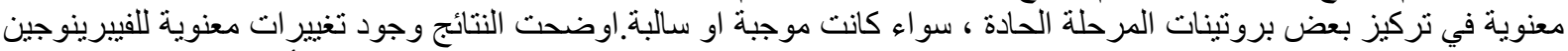

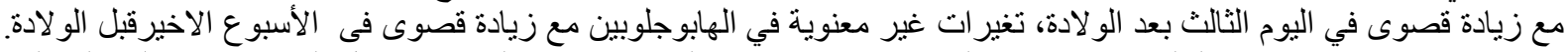

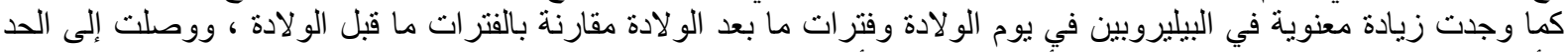

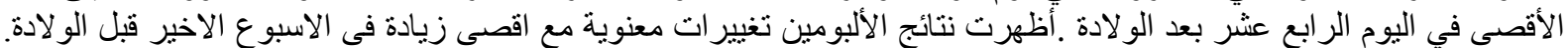

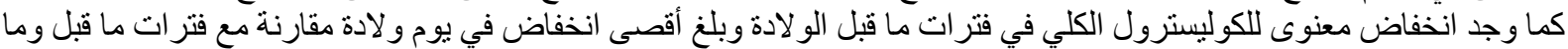

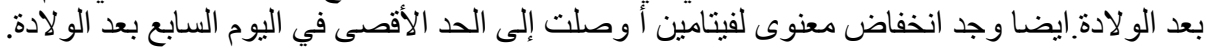

